\title{
Complete 2D NMR assignment and antifungal activity of ishwarane isolated from Hortonia, a genus endemic to Sri Lanka
}

\author{
Rukmal Ratnayake ${ }^{1}$, Susanthi Jayasinghe ${ }^{1}$, B.M. Ratnayake Bandara ${ }^{1}$, Raymond J. Andersen ${ }^{2}$ and \\ Veranja Karunaratne ${ }^{1^{*}}$ \\ 1 Department of Chemistry, University of Peradeniya, Peradeniya, Sri Lanka. \\ 2 Department of Earth \& Ocean Sciences, University of British Columbia, Vancouver, B.C., Canada.
}

\begin{abstract}
The tetracyclic sesquiterpene, ishwarane, was isolated from the leaves of the representative species of the genus Hortonia, H. angustifolia, H. floribunda and H. ovalifolia collected in Sri Lanka. The complete 2D NMR assignments are reported. Ishwarane exhibited antifungal activity against Cladosporium cladosporioides.
\end{abstract}

Keywords: Antifungal activity, Hortonia, ishwarane, 2D NMR assignments, Sri Lanka.

\section{INTRODUCTION}

The genus Hortonia is endemic to Sri Lanka and belongs to the Order Laurales and Family Monimiaceae. Members of this family are weeds or shrubs and rarely climbers. This family comprises of about 39 genera and 440 species which are widely spread in the Southern Hemisphere, mainly tropical and subtropical regions of the Americas ${ }^{1}$. Members of Family Monimiaceae are present in Sri Lanka, Oceania, Polynesia, Australia, Malaysia, Madagascar and South America ${ }^{1,2}$. They are very rare in Africa and absent in India. Siparuna and Mollinedia comprising of 150 and 94 species respectively are the two major genera of Monimiaceae ${ }^{2}$.

Dassanayake (1996) lists three distinct Monimiaceae species $\{H$. floribunda Wight ex Arn., H. angustifolia (Thw.) Trimen and H. ovalifolia Wight $\}$ in Sri Lanka ${ }^{3}$. Some phytogeographers consider the genus Hortonia to have originated in Gondwanaland about 100-200 million years $\mathrm{ago}^{4}$. The present study was initiated with a view to isolating the bioactive compounds from the plants of genus Hortonia in Sri Lanka.
Although three species of Hortonia are found in a range of environments from sea level ( $H$. angustifolia) to the montane (H. floribunda and H. ovalifolia) regions, there have been no reports of the medicinal use of these plants in Sri Lanka. It has been previously reported that the bioassay-guided fractionation of the dichloromethane extracts of all three species yielded two mosquitolarvicidal butenolides $^{5}$. Herein we report the isolation, complete 1D and 2D NMR assignment and the antifungal activity of the sesquiterpene hydrocarbon ishwarane from all three species of Hortonia.

\section{METHODS AND MATERIALS}

Analytical Thin Layer Chromatography (TLC) was performed on Merck Kieselgel $60 \mathrm{~F}_{254}$ aluminium foil plates. TLC plates were visualized by spraying with anisaldehyde followed by heating. Medium Pressure Liquid Chromatography (MPLC) and flash chromatography were performed on Merck Kieselgel 60 (230-400 mesh ASTM). ${ }^{1} \mathrm{H}$ and ${ }^{13} \mathrm{C}$ NMR, COSY, DEPT, HETCOR, HMQC and HMBC spectra were recorded on a VARIAN $\left({ }^{1} \mathrm{H} 500\right.$ and ${ }^{13} \mathrm{C} 125 \mathrm{MHz}$ ) in $\mathrm{CDCl}_{3}$ with TMS as the internal standard. EIMS were recorded on a Fisons VG Autospec mass spectrometer operating at $70 \mathrm{eV}$ (direct insertion). Perfluorokerosine was used as the internal reference for HRMS measurements.

Specimens of $H$. angustifolia were collected from Kanneliya (Southern Province), H. floribunda from Hakgala (Central Province), and $H$. ovalifolia from the foothills of Adam's Peak (Central Province) 
in September 1998. The plants were identified by Dr. D.S.A. Wijesundara, Director, Royal Botanic Gardens, Peradeniya and voucher specimens were deposited at the National Herbarium, Peradeniya.

Air-dried, powdered leaves of $H$. angustifolia were extracted repeatedly into $\mathrm{CH}_{2} \mathrm{Cl}_{2}(3 \times 500 \mathrm{~mL})$ at $27{ }^{\circ} \mathrm{C}$. The combined $\mathrm{CH}_{2} \mathrm{Cl}_{2}$ extract was concentrated in vacuo, to obtain brown oil $(25 \mathrm{~g})$. The oil was subjected to MPLC on Si gel [step gradient hexane to hexane/methanol $(95: 5)]$ to give several fractions. The first fraction $(2.26 \mathrm{~g})$ showed antifungal activity. This was subjected to flash chromatography on silica gel (30 g) (eluent: $\mathrm{CH}_{2} \mathrm{Cl}_{2}$ hexane, $1: 1)$ to give ishwarane $(100 \mathrm{mg})(0.4 \%)$ as a colourless oil. Similarly Ishwarane, was isolated from the leaves of $H$. floribunda and $H$. ovalifolia in comparable yields using identical chromatographic conditions. ${ }^{1} \mathrm{H}$ NMR (500 MHz, $\left.\mathrm{C}_{6} \mathrm{D}_{6}\right) ;{ }^{13} \mathrm{C}$ NMR (125 MHz, $\left.\mathrm{C}_{6} \mathrm{D}_{6}\right)$ : See Table 1; HRESIMS [M] ${ }^{+}: 204.18785$ (calculated for $\mathrm{C}_{15} \mathrm{H}_{24}, 204.18780$ ).

Antifungal assay was carried out on pure ishwarane (1 mg). An aqueous solution of benomyl, 50\% w.p. \{methyl 1-[(butylamino) carbonyl]-H-benzimidazol2-ylcarbamate ( $1 \mathrm{mg}$ ) were used in the assays for comparison purposes. TLC plates (silica gel $\mathrm{PF}_{254=366}$, $0.5 \mathrm{~mm} \times 20 \mathrm{~cm} \times 20 \mathrm{~cm}$ ) were spotted with pure ishwarane and the aqueous solution of Benor eluted with $\mathrm{CH}_{2} \mathrm{Cl}_{2}$, and then air dried (overnight) to evaporate all traces of remaining solvents. A spore suspension of Cladosporium cladosporioides in Czapek-dox nutrient solution (CNS) was sprayed on to the plates and incubated in a moist chamber at $28 \pm 2{ }^{\circ} \mathrm{C}$ for two days. Diameter of the inhibition zones were measured ${ }^{6}$.

Conidia (5-7 d old) of C. cladosporioides were suspended in sterile distilled water and was passed through glass wool to remove mycelia. The conidia were washed three times by centrifugation ( $3 \mathrm{~min}$ at $3000 \mathrm{rpm}$ ) and resuspension of the resulting pellet in sterile distilled water. Conidia in the suspension were adjusted to about $5 \times 10^{2} \mathrm{~mL}^{-1}$. A series of solutions of the compound was prepared in $10 \% \mathrm{EtOH}$ in water. Drops $(10 \mu \mathrm{L})$ from each were placed on clean glass slides. Care was taken to apply the drops over a uniform area on the glass slides. The control was prepared without the compound. The glass slides were then incubated in a moist chamber for $6 \mathrm{~h}$ at room temperature. Germination was stopped at the end of the incubation period by adding a drop of lactophenol.

Table 1: 1D and 2D NMR spectroscopic data of ishwarane

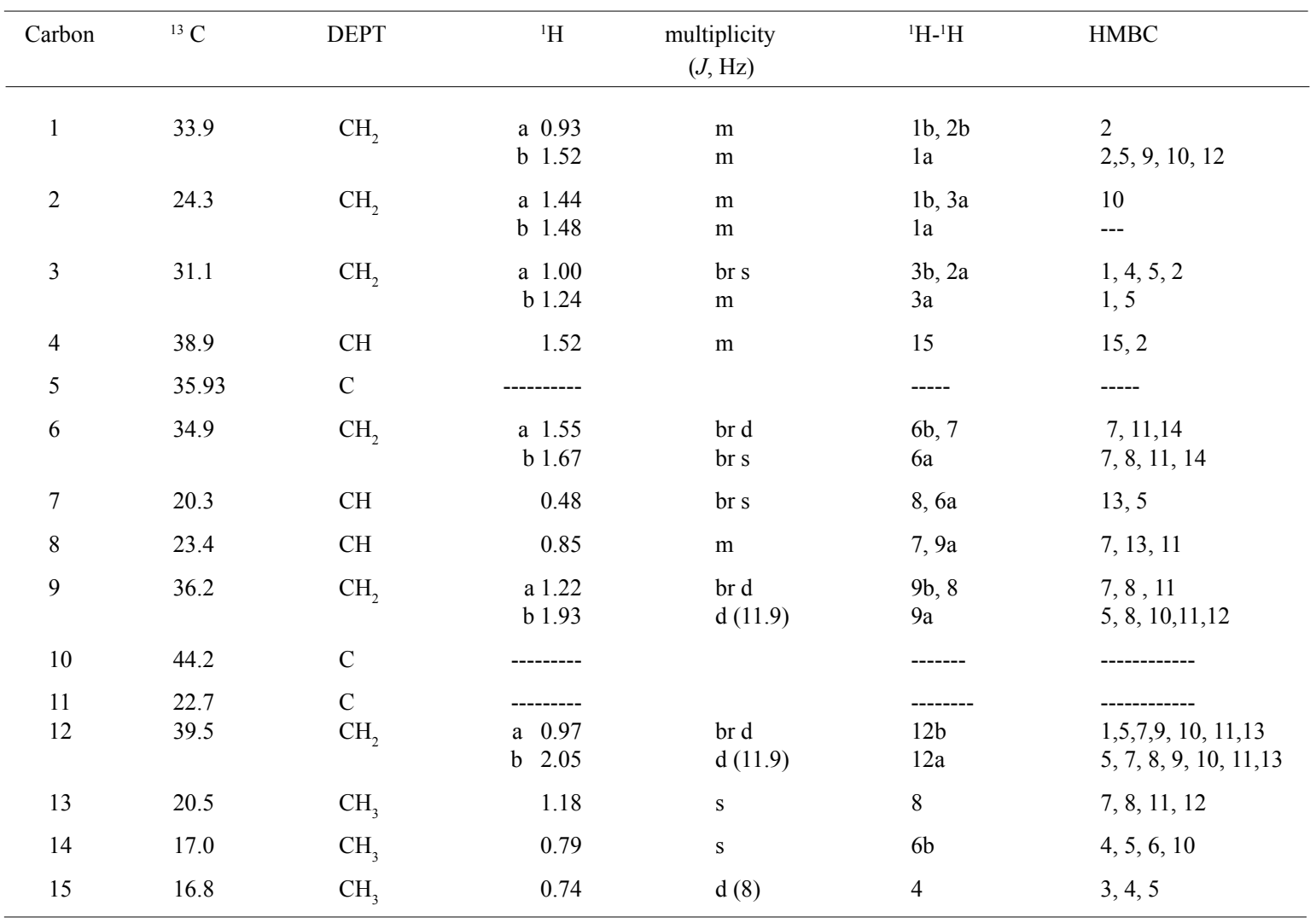


Four randomly selected areas on each slide were observed under a microscope and germinated and non-germinated conidia were counted. Percentage germination was determined by using average values of the four replicates?

\section{RESULTS AND DISCUSSION}

Ishwarane was first isolated from the plants Aristolochia indica $^{8}$ and Cembopentalum penduliflorum ${ }^{9}$. It has been isolated from the essential oils of Bixa orellana ${ }^{10}$, Corallocarpus epigaeus ${ }^{11}$ and Piper fulvescens ${ }^{12}$. Its structure was elucidated 35 years ago by chemical transformations and spectroscopic techniques ${ }^{8,9,13}$ (Figure 1). The oxygenated derivatives ishwarol ${ }^{14}$ and ishwarone ${ }^{15}$ have been reported from the essential oils of Aristolochia indica and more recently, ishwarol B was isolated from the essential oils of Cedrelopsis grevei ${ }^{16}$.

Ishwarane $\left(\mathrm{C}_{15} \mathrm{H}_{24}, \mathrm{M}^{+}\right.$204.1) was isolated from the $\mathrm{CH}_{2} \mathrm{Cl}_{2}$ extracts of the leaves of all three species of Hortonia in identical yields by MPLC followed by column chromatography and was subjected to a full set of 1D and 2D NMR experiments (Table 1).

Interestingly, it showed antifungal activity against C. cladosporioides (Table 2). A recent report showed that the essential oil from Piper guineense from Nigeria containing ishwarane inhibited the growth of Pseudomonas aeruginosa UCH 655 strain $^{17}$. The occurrence of ishwarane in all the representative species in the genus Hortonia is of chemotaxonomic significance.

Table 2: Antifungal activity of ishwarane against $C$. cladosporioides

\begin{tabular}{lcc}
\hline Compound & $\begin{array}{l}\text { Diameter }(\mathrm{mm}) \text { of the } \\
\text { Inhibition zone }\end{array}$ & $\%$ Germination ${ }^{\mathrm{b}}$ \\
\hline Ishwarane & 23 & 2.5 \\
$\begin{array}{l}\text { Control } \\
\text { (Benor) }\end{array}$ & 37 & 0 \\
\hline
\end{tabular}

\footnotetext{
a In the TLC bioassay

b Spore germination assay at $6.25 \mathrm{ppm}$. Concentrations higher than $6.25 \mathrm{ppm}$ produced zero germination. The control benomyl \{methyl-1- (butylcarbonyl)-2- benzimidazolecarbamabamate\} produced $0 \%$ germination at all concentrations.
}

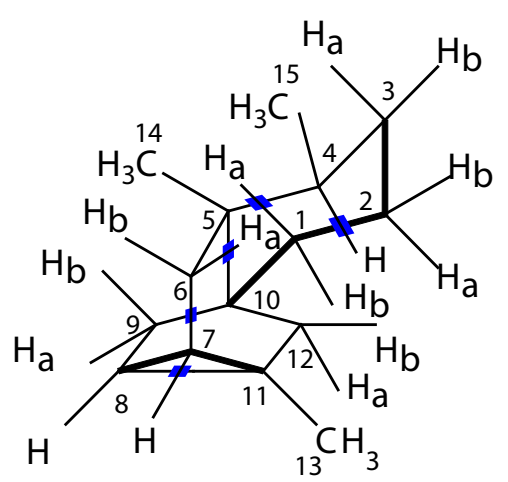

Figure 1: Ishwarane (numbering of carbons according to Joulain and Konig ${ }^{18}$ )

\section{References}

1. Leitão G.G., Soares S.S.V., de Barros T., Brito M. \& Monache F.D. (2000). Kaempferol glycosides from Siparuna apiosyce. Phytochemistry 55: 679-682.

2. Claros B.M.G., da Silva A.J.R., Vasconcellos M.L.A.A., de Brito A.P.P. \& Leitao G.G. (2000). Rotundifolides A and $\mathrm{B}$, two new enol-derived butenolactones from the bark of Litsea rotundifolia var. Oblongifolia. Phytochemistry 55: $859-862$.

3. Dassanayake M.D. (1996). A Revised Handbook to the Flora of Ceylon, Volume X; Oxford \& IBH Publishing Co. Pvt. Ltd., New Delhi, pp. 282-285.

4 Jayasekara R. (1997). Arjuna's Atlas of Sri Lanka. (Eds. T. Somasekaram, M.P. Perera, M.B.G. de Silva \& H. Godellawatte pp. 36. Arjuna Consulting Co. Ltd., Dehiwala.

5. Ratnayake R., Karunaratne V., Ratnayake Bandara B.M., Kumar V., MacLeod J.K., Simmonds P. (2001). Two new lactones with mosquito larvicidal activity from three Hortonia species. Journal of Natural Products 64: 376378.

6. Klarman W.L. \& Stanford J.L. (1968). Isolation and purification of an antifungal principle from infected soybeans. Life Sciences 7: 1095-1103.

7. Anon (1943). In: Slide germination evaluating fungicides. American Phytopathological society, Committee on standardization of fungal tests 33: 627.

8. Govindachari T.R., Mohamed P.A., Parthasarathy P.C. (1970). Ishwarane and aristolochene, two new sesquiterpene hydrocarbons from Aristolochia indica. Tetrahedron 26: 615.

9. Teng L.C. \& DeBardeleben J.F. (1971). A novel tetracyclic sesquiterpene from the oil of Orejuela of Cymbopetalum penduliforum (Dunal). Experientia 15: 27(1):14-5.

10. Lawrence B.M. \& Hogg J.W. (1973). Ishwarane in Bixa orellana leaf oil. Phytochemistry 12: 2995.

11. Gupta J., Ali M., Pillai K.K., Velasco-Negueruela A., Perez-Alonso M.J. \& Gomez Contreas F. (1997). Isolation and structure elucidation of ishwarol B. Journal of Essential Oil Research 9: 667. 
12. Vila R., Milo B., Tomi F., Casanova J., Ferro E.A. \& Cañigueral S. (2001). Composition and antifungal activity of essential oils from Piper aduncum, Piper arboreum and Piper tuberculatum. Journal of Ethnopharmacol 76: 105.

13. Cory R.M. \& Sotothers J.B. (1978). Isolation and structure elucidation of ishwarol B. Organic Magnetic Resonance 11: 252 .

14. Govindachari T.R. \& Parthasarathy P.C. (1971). Cluytyl ferulate, a new long chain ester from Gmelina arborea Linn. \& Lannea grandis (Dennst). Indian Journal of Chemistry 9: 1310.

15. Govindachari T.R., Nagarajan K. \& Parthasarathy P.C. (1969). Total synthesis of tetracyclic sesquiterpenoids:
$( \pm)$-ishwarone. Cheical Communication 14: 823.

16. Cavalli J.F., Tomi F., Bernardini A.F. \& Casanova J. (2003). Dihydroagarofurans: the fourth isomer isolated from Cedrelopsis grevei bark oil. Flavour Fragrance Journal 18: 532.

17. Oyedeji O.A., Adeniyi B.A., Ajayi O. \& König W.A. (2005). Essential oil composition of Piper guineense and its antimicrobial activity: another chemotype from Nigeria. Phytotherapy Research 19 (4): 362-364.

18. Joulain D., Konig W.A. (1998). The Atlas of Spectral Data of Sesquiterpene Hydrocarbons. E.B.-Verlag: Hamburg, Germany. 